ests and social forces. The theoretical payoff of a study of this kind would be enhanced by case studies that take a longer view, combining a focus on the politics of decision (and redecision) with an exploration of what is necessary for policy changes to take effect in the bureaucratic and social context.

George Breslauer

University of California, Berkeley

\title{
KHRUSHCHEV AND THE DEVELOPMENT OF SOVIET AGRICULTURE: THE VIRGIN LAND PROGRAMME 1953-1964. By Martin McCauley. New York: Holmes \& Meier, 1976. xiv, 232 pp. Maps. $\$ 24.00$.
}

The title of this book is somewhat deceptive. Although the main title implies a rather broad treatment of the Khrushchev years, the subtitle does not. At the outset, the author states that "this study is concerned with the economic and political record of the Virgin Lands over the years 1953-64." However, the book covers a much longer span of years than that suggested in the subtitle, and the broader treatment of the Khrushchev years does not materialize.

In regard to the Virgin Lands program, the author has done a good job. This work falls between those that analyze the upper-level political decision-making process and those that would look only at such a program on a cost-benefit basis. The author provides an excellent background discussion and succeeds in presenting a rich picture of the political, economic, and technical dilemma facing Khrushehev in the 1950s. Even in the face of limited data, most will be able to accept the author's conclusion that "Khrushchev's bold démarche in going east in 1954 was correct."

Insofar as the author attempts to deal with the broader questions of Soviet agricultural development during the Khrushchev years, this study is less satisfactory. There is, for example, considerable discussion of extensive versus intensive development of agriculture, paths of development which are said to appear contradictory (p. 122). Surely, however, any such transformation from an extensive to an intensive path of agricultural development will be gradual, so that during any transition period both policies may in fact be operative. In this context, the author does not devote enough attention to the efforts toward intensification made during the Khrushchev years. There was considerable effort to improve the quality of the labor input (especially at the managerial and technical levels) during that period, but Western studies on the subject (for example, Millar's The Soviet Rural Community) are not mentioned. The author emphasizes the then prevailing Soviet view of the need for control in the countryside, but one of the most important mechanisms of such control, namely the MTS, is mentioned only briefly, and standard works, such as Miller's One Hundred Thousand Tractors, are not cited.

One could note other examples. Khrushchev emphasized (as the author notes) the need for the improvement of material incentives in agriculture. In large measure, however, Khrushchev's emphasis was translated into reality, though the author does not cite the available data on this matter. Finally, the reorganization of collective farms is given only brief mention, even though the sharp increase in the volume of inputs over which a typical farm manager had control during the Khrushchev years must have drastically altered the manner in which farm decision making was being carried out.

All of these areas of Khrushchev's emphasis were overshadowed by the more grandiose nature of the Virgin Lands program. But for the long-term development of Soviet agriculture, Khrushchev's efforts toward intensification must be taken seriously. Judged in a broader perspective than simply the Virgin Lands, this reviewer would be hesitant to accept the author's conclusion that "taken as a whole, Khrushchev's 
efforts in the agricultural sphere must be judged as having enjoyed relatively little success."

As a study of the Virgin Lands program, the background to that program, and Khrushchev's role in its development, the book succeeds, and should be read by anyone interested in Soviet agricultural development. As a more general study of the Khrushchev record, and in particular of the balance among the various themes promoted by Khrushchev, this work is less satisfactory. To be fair, the author may have intended to treat only the narrower theme, but the substance of the book and the conclusions drawn suggest otherwise.

Robert C. STUART

Rutgers University

THE SOVIET UNION SINCE THE FALL OF KHRUSHCHEV. Edited by Archie Brown and Michael Kaser. New York: The Free Press, Macmillan, 1975. xiv, 294 pp. $\$ 13.95$.

In this compendium several British scholars examine the Soviet scene during the first decade under Brezhnev. Their aim is to provide a broad readership with "a thoroughly informed, up-to-date [mid-1975] survey of the changes that have taken place . . . since Khrushchev's departure" ( $p$, xi). While not exhaustive, the work manages effectively to cover major social, economic, and political developments of the period. Successive chapters deal with agriculture, the import of Western technology, foreign and defense. policies, demographic developments, the changing composition of the Communist Party, dissent and opposition, religion, and literature. While nationality problems are not dealt with separately, relevant data appear in the articles on demography and religion. The essays by Alec Nove (on agriculture) and Peter Reddaway (on dissent) deserve special praise for their scholarship and lucidity.

Two final essays contain general assessments of the economy and polity. Unfortunately, the first of these, by Michael Kaser, will prove difficult for the reader without special knowledge of economic or Soviet affairs. Archie Brown's overview of political trends, which includes careful attention to the political implications of the earlier chapters, admirably rounds out the collection. Students will find useful the "Calendar of Political Events" (from October 14, 1964 to April 16, 1975).

This is a timely and valuable survey.

Jan S. Adams

Ohio State University

POLITICAL CONTROL OF THE SOVIET ARMED FORCES. By Michael $J$. Deane. New York: Crane, Russak \& Company, 1977. xi, 297 pp. \$17.50.

SOVIET ARMED FORCES REVIEW ANNUAL, vol. 1, 1977. Edited by David R. Jones. Gulf Breeze, Fla.: Academic International Press, 1977. x, 277 pp. $\$ 29.50$.

Growing interest in the Soviet military has spurred Western scholars to an intensification of the research efforts needed to help shed light on this complex and often confusing subject. The two books under review approach this task from different perspectives. Michael Deane's book focuses on the role of the Main Political Administration (MPA), while the work edited by David Jones touches on many different aspects of the Soviet military.

The purpose of Deane's book is to "define types of interest groups represented by the MPA, the Party and the professional military" ( $\mathrm{p}$. viii). Providing a historical overview of party-army relations from 1917 to Ustinov's promotion to defense min- 